\title{
Preliminary Study of Total Suspended Solid Distribution in Coastal Ujung Pangkah Gresik Based Reflectance Value of Landsat Satellite Imagery
}

\author{
Hendrata Wibisana ${ }^{1^{*}}$, Bangun Muljo Soekotjo ${ }^{2}$ and Umboro Lasminto ${ }^{1}$ \\ ${ }^{1}$ Universitas Pembangunan Nasional "Veteran" Jawa Timur, Indonesia \\ ${ }^{2}$ Geomatics Engineering ITS Surabaya Indonesia \\ ${ }^{3}$ Civil Engineering, ITS Surabaya, Indonesia
}

Received: 2018-10-21

Accepted: 2019-02-21

Keywords:

coastal;

landsat satellite;

reflectance value;

total suspended solis .

Corespondent Email:

hendrata2008@gmail.com

\begin{abstract}
Total suspended solid (TSS) is one of the parameters that uses for detecting health in aquatic environments. The distribution of the TSS value in the water body will affect the aquatic ecosystem. In this research will be analyzed the distribution value of TSS during 5 year period by utilizing Landsat 8 satellite image data, where the developed method is extraction of reflectance value from Landsat 8 satellite image for 5 years using SEADASS and then compiled the TSS algorithm with reflectance value that already obtained on the existing conditions, the algorithm obtained is estimated over 5 years back to get a picture of change and distribution of TSS value. As a case study, the coast of Ujung Pangkah Gresik was taken which has the mouth of the river Bengawan Solo. The results obtained from this study illustrate the decrease of TSS value during that time period, so that with this decrease can be concluded that at the point of field coordinate, TSS value was decreasing and causing the erosion in the environment.
\end{abstract}

(๑) 2019 by the authors. Licensee Indonesian Journal of Geography, Indonesia.

This article is an open access article distributed under the terms and conditions of the Creative Commons Attribution(CC BY NC) licensehttps://creativecommons.org/licenses/by-nc/4.0

\section{Introduction}

Total suspended solid is one of the parameters use for detecting contamination in a waters. The concentration number of this parameter can be used as a reference in determining the level of pollution that occurs. The content of large TSS values will affect the ecosystem in these waters. To determine the concentration of TSS can be done by measurement in the laboratory, through various methods that have been done by many environmental analysts, where one of them is the method of Gravimetric (Baxter, 2017; Kari, Kratzer, Beltrán-Abaunza, Harvey, \& Vaičiūte, 2017; Tan, Thishalini, Goh, \& Edlic, 2017). In relatively shallow water environments such as coastal areas, the value of TSS may vary depending on several parameters such as coastal morphology, the presence of river flow to the coast, tides of sea water and currents. (Dunn, Zigic, Burling, \& Lin, 2015; Hou et al., 2017; Thiruvenkatasamy \& Baby Girija, 2014)

The preliminaries research about total suspended matter have been work by some research for MODIS satellite (Cavalli, 2017; Chen et al., 2015; Dorji \& Fearns, 2016; Hou et al., 2017), Geostationary ocean color imager (GOCI) (Hwang, Choi, Ryu, \& Frouin, 2018) and for Meris (Guillou, Rivier, Gohin, \& Chapalain, 2015; Shuchman et al., 2013) and also with Landsat 5 and then Landsat 7 ETM (Claverie, Vermote, Franch, \& Masek, 2015; Ozesmi \& Bauer, 2002; Sullivan, White, \& Vepraskas, 2017; Wang et al., 2017), they found that there is connection between surface reflectance from the sensor of the image satellite with the distribution of total suspended solid. For monitoring purposes where is it could covered a wider scale of picture, remote sensing technology can be used, where with this technology, it could saved a lot of time and cost, because remote sensing has several advantages in monitoring of changes in natural resources such as spatial and temporal resolution. Remote sensing has been widely used in monitoring the quality of water on the coast and offshore, the results obtained are data from satellite images that can be utilized to build a remote sensing algorithm (Wibisana, Sukojo, \& Lasminto, 2018; Zhang et al., 2011) to several parameters such as total suspended solid concentration, chlorophyll, salinity, in addition to climatological aspects such as value of sea surface temperature.

Furthermore, until now the phenomena not known with certainty about the distribution pattern of TSS in the coastal Gresik, although is it known in the area of sedimentation and acretion is quite high due to the flow of Bengawan Solo river that moves into the Ujung Pangkah Gresik. The aim of this research is to detect the distribution and develop remote sensing algorithm for total suspended solid which is adequate to be applied on coastal area especially in Ujung Pangkah Gresik area for 5 year period using Landsat 8 OLI satellite image starting from 2013 until condition of existing year 2017

\section{Methods}

Ujung Pangkah Gresik is located in nothern East Java Indonesia between $6^{\circ} 50^{\circ} 50^{\circ} \mathrm{S}$ and $6^{\circ} 55^{\circ} \quad 14^{\circ}$ 
$\mathrm{S}$, and $112^{\circ} 30^{\circ} 00^{\circ} \mathrm{E}$ and $112^{\circ} 33^{\circ} 47^{\circ} \mathrm{E}$. It is the largest ponds located at the nothern end of Gresik regency, with a total ponds area of about $2,147 \mathrm{~km} 2$. It is a shallow lake, with mean depth $2.3 \mathrm{~m}$, and maximum depth $3.6 \mathrm{~m}$ at a water surface elevation of $2.0 \mathrm{~m}$ above sea level. The Ujung Pangkah Gresik (Figure 1.) is the most cultivated area in nothern East Java with high population density and famous for fishing and fisheries.

Furthermore, to obtain the distribution of Total Suspended Solid in the coast of Ujung Pangkah Gresik , there are few of stage of algorithm to be build to get the value of it, according to the coordinate which have chosen with used of handheld GPS (Figures 1)

\section{Retrieve of TSS Field Data and Satellite Imagery}

Total suspended solid (TSS) data were obtained by sampling of seawater at a depth of 20 - 30 centimeters from the sea surface boundary by a fishing boat using a 1 liter capacity plastic bottle. The retrieval was carried out at 20 points measured by field coordinates using a GPS handheld. The number of samples was chosen because 20 of them represented color interval from the initial display of satellite imagery in composite colors, where each color difference was identified and 2 point were selected from 10 difference color area to obtain 20 observation point in the coastal of Ujung Pangkah. After collecting seawater samples, TSS was measured by Gravimetric method. The process of filtering seawater done by using whatmann filter paper, and then continue to dry with the oven at a temperature of 100 o Celsius. The filter paper is weighed with an analytical balance and measured by weight of TSS by the formula 1 .

$$
W_{T S S}=W_{T o T}-W_{P}
$$

$\mathrm{W}(\mathrm{TSS})=$ weight of TSS

$\mathrm{W}(\mathrm{ToT})=$ total weight (filter paper + TSS $)$

$\mathrm{W}(\mathrm{P})=$ weight of filter paper

The weight of TSS are recorded for each coordinate and the concentration is expressed in units of milligrams / liter or (mg / 1).

Satellite images which use for the study are a Landsat 8 OLI Level 1 for the year 2013 until the year 2017, this images data retrieve from the web Earthexplorer (DAAC, 2017), with path 118 and row 65 for the scene of coast Ujung Pangkah Gresik ( Table 1. ) Figure 1 is the location of the study in the Ujung Pangkah Gresik

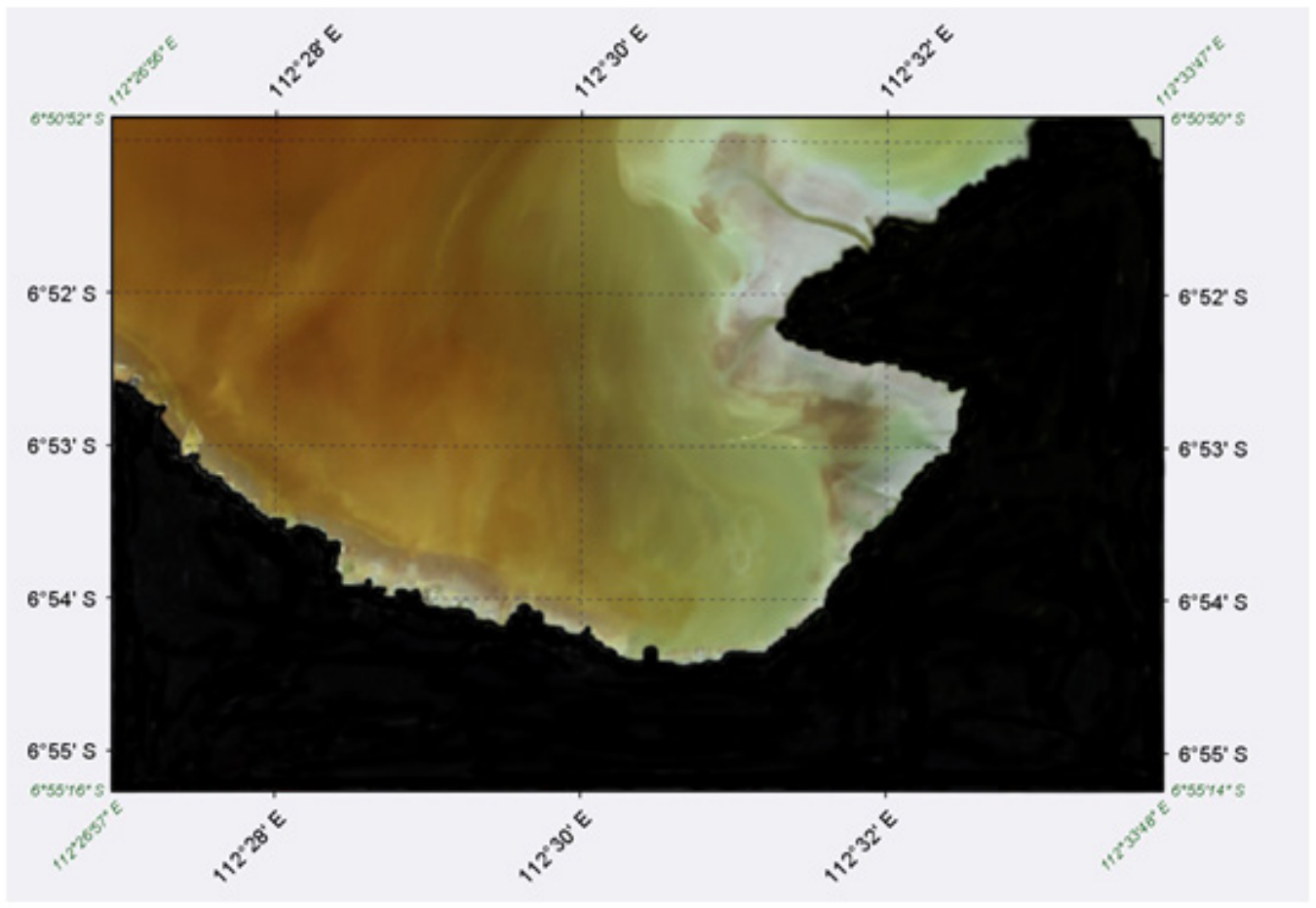

Figure 1. Research Location at Coast of Ujung Pangkah Gresik

Table 1. Retrieve of Landsat 8 OLI on Path 118 and Row 65

\begin{tabular}{lllc}
\hline Path & Row & File & Acquisition \\
\hline 118 & 65 & LC08_L1TP_118065_20171027_20171107_01_T1 & 27 October 2017 \\
118 & 65 & LC08_L1TP_118065_20161024_20170318_01_T1 & 24 October 2016 \\
118 & 65 & LC08_L1TP_118065_20151022_20170402_01_T1 & 22 October 2015 \\
118 & 65 & LC08_L1TP_118065_20141019_20170418_01_T1 & 19 October 2014 \\
118 & 65 & LC08_L1TP_118065_20131016_20170429_01_T1 & 16 October 2013 \\
\hline
\end{tabular}


area, where the image represents the Landsat 8 satellite image for a combination of channels 3,2 and 1 that produce composite colors. The satellite image was acquired on October 27, 2017 where the tides at the time of shooting were 0.5 meters for the lowest and 1.5 meters for the highest. This data was obtained from the Karang Jamuang Gresik tidal observation station for observations carried out for 24 hours. When satellite imagery taken by the OLI sensor on Landsat 8 when shooting is at an interval of 10 hours to 12 noon and at that time the lowest tide is 0.5 meters .

\section{Surface Reflectance Extraction of Satellite Imagery}

The value of surface reflectance from Landsat 8 satellite was retrieve by SEADASS version 7.2. This value is in the visible wavelength range of wavelengths consisting of channel 1, channel 2, channel 3 and channel 4, in which Landsat 8 represents for Aerosol channel wavelength, blue channel, green channel and red channel ( Table.2 ).

The value of the obtained surface reflectant is used to detect the TSS concentration value by calculating the best algorithm of the mathematical model obtained on each of the available channels.

\section{Algorithm for Total Suspended Solid}

To obtain the distribution value of the total suspended solid from the existing condition, the appropriate algorithm is needed to obtain a mathematical model that can describe the relationship between the reflecting surface of the satellite image and the TSS value in the field. In this study the algorithm developed to measure the distribution of TSS is by using linear model, exponent, logarithmic, quadratic, cubic and power. The model form for each developed algorithm is:

Linier: $y=\mathbf{x}+\mathrm{b}$

Exponent: $y=a \cdot e^{b \cdot x}$

Logaritmic: $y=a \cdot \ln (x)+b$

Quadratic: $y=a \cdot x^{2}+b \cdot x+c$

Cubic: $y=a \cdot x^{3}+b \cdot x^{2}+c \cdot x+d$

Power: $y=a \cdot x^{b}$

Note: $a, b, c$ and $d$ are coefficients of the variable $x$ representing the reflectant surface, whereas $y$ is the variable representing the field TSS value.

From a series of selected algorithms with the appropriate mathematical model, it will be calculated on the channels of the Landsat 8 satellite image, channel 1 to channel 4 are the channel which is selected where they have the best correlation by looking at the $\mathrm{R} 2$ value of each model for each the corresponding channel. Channels that provide the best R2 values from others will be selected as reference channels for field TSS validation.

For processing with algorithm to obtain a mathematical model it's used 14 data value of TSS from 20 existing data, then the six data remaining were used for model validation process from selected algorithm.

\section{Result and Discusion}

Total Suspended Solid Data

The TSS data obtained is shown in Table 3, from laboratory measurements of TSS values expressed by milligrams / liter.

Table 2. Characteristic of Optical Band Landsat 8 OLI

\begin{tabular}{llll}
\hline Band Spectral & Long wave $(\mu \mathrm{m})$ & Resolution & \\
\hline $\begin{array}{l}\text { Band 1 - Coastal } \\
\text { Aerosol }\end{array}$ & $0,43-0,45$ & $30 \mathrm{~m}$ & Research in Coastal and Aerosol \\
Band 2 - Blue & $0,45-0,51$ & $30 \mathrm{~m}$ & $\begin{array}{l}\text { Bathymetric mapping, distinguishing } \\
\text { soil from vegetation and deciduous } \\
\text { from coniferous vegetation }\end{array}$ \\
Band 3 - Green & $0,53-0,59$ & $30 \mathrm{~m}$ & $\begin{array}{l}\text { Emphasizes peak vegetation, which is } \\
\text { useful for assessing plant vegetation } \\
\text { Discriminates vegetation slopes }\end{array}$ \\
Band 4 - Red & $0,64-0,67$ & $30 \mathrm{~m}$ & Dirce: United State of Geological Surveys (USGS), NASA
\end{tabular}

Table 3. Algorithm Model of Band 2 (Blue Band) from Landsat 8 OLI

\begin{tabular}{lll}
\hline Model Algorithm & Mathematical equation & R2 \\
\hline Linier & $\mathrm{y}=1075,6 \mathrm{x}-80,219$ & 0.794 \\
Exponent & $\mathrm{y}=3,5658 \mathrm{e} 21,732 \mathrm{x}$ & 0.766 \\
Logaritmic & $\mathrm{y}=130,63 \ln (\mathrm{x})+325,95$ & 0.794 \\
Quadratic & $\mathrm{y}=-781,46 \mathrm{x} 2+1266,2 \mathrm{x}-91,81$ & 0.794 \\
Cubic & $\mathrm{y}=3 \mathrm{E}+06 \mathrm{x} 3-1 \mathrm{E}+06 \mathrm{x} 2+$ & 0.818 \\
& $135741 \mathrm{x}-5527,2$ & \\
Power & $\mathrm{y}=13435 \mathrm{x} 2,6524$ & 0.773 \\
\hline
\end{tabular}


Indonesian Journal of Geography, Vol. 51 No. 1, April 2019 : 42 - 48

Table 4. TSS Data in-situ with UTM Coordinates

\begin{tabular}{|c|c|c|c|}
\hline \multicolumn{3}{|c|}{ UTM Coordinated } & $\begin{array}{l}\text { TSS insitu } \\
(\mathrm{mg} / \mathrm{l})\end{array}$ \\
\hline & $\mathrm{X}$ & $\mathrm{Y}$ & \\
\hline \multicolumn{2}{|c|}{665700,2666} & 9236743,846 & 35,2 \\
\hline \multicolumn{2}{|c|}{665889,6972} & 9236654,475 & 65,7 \\
\hline \multicolumn{2}{|c|}{666162,7517} & 9236508,011 & 41,3 \\
\hline \multicolumn{2}{|c|}{666421,7628} & 9236386,472 & 54,5 \\
\hline \multicolumn{2}{|c|}{666791,0634} & 9236388,989 & 52,6 \\
\hline \multicolumn{2}{|c|}{667070,0665} & 9236376,738 & 48,7 \\
\hline \multicolumn{2}{|c|}{667363,0936} & 9236430,485 & 51,8 \\
\hline \multicolumn{2}{|c|}{667694,8104} & 9236487,18 & 52,9 \\
\hline \multicolumn{2}{|c|}{667950,054} & 9236532,443 & 46,1 \\
\hline \multicolumn{2}{|c|}{668159,4246} & 9236728,064 & 49,5 \\
\hline \multicolumn{2}{|c|}{668391,1365} & 9236901,803 & 53,7 \\
\hline \multicolumn{2}{|c|}{667323,0723} & 9236491,127 & 46,2 \\
\hline \multicolumn{2}{|c|}{668532,7179} & 9237113,305 & 44,7 \\
\hline \multicolumn{2}{|c|}{668680,185} & 9237341,07 & 51,5 \\
\hline \multicolumn{2}{|c|}{668794,4607} & 9237556,96 & 55,3 \\
\hline \multicolumn{2}{|c|}{668918,299} & 9237786,95 & 52,4 \\
\hline \multicolumn{2}{|c|}{669088,065} & 9237979,01 & 53,7 \\
\hline \multicolumn{2}{|c|}{669282,1414} & 9238188,808 & 63,1 \\
\hline \multicolumn{2}{|c|}{669647,7817} & 9238575,298 & 66,3 \\
\hline \multicolumn{2}{|c|}{669925,8796} & 9238849,641 & 64,7 \\
\hline \multicolumn{4}{|c|}{$\begin{array}{l}\text { Table 5. Algorithm Model of Band } 3 \text { (Green Band) } \\
\text { from Landsat } 8 \text { OLI }\end{array}$} \\
\hline $\begin{array}{l}\text { Model } \\
\text { Algorithm }\end{array}$ & \multicolumn{2}{|c|}{ Mathematical equation } & $\mathrm{R} 2$ \\
\hline Linier & \multicolumn{2}{|c|}{$y=844,15 x-45,952$} & 0.712 \\
\hline Exponent & \multicolumn{2}{|c|}{$y=6,3033 e 18,139 x$} & 0.776 \\
\hline $\begin{array}{l}\text { Logaritmic } \\
\text { Quadratic }\end{array}$ & \multicolumn{2}{|c|}{$y=88,054 \ln (x)+241,61$} & 0.686 \\
\hline Quadratic & $\begin{array}{l}y= \\
278\end{array}$ & $31 x 2-5278 x+$ & 0.799 \\
\hline Cubic & $\begin{array}{l}y= \\
131\end{array}$ & $\begin{array}{l}-06 \times 3-1 E+06 \times 2+ \\
x-4573,6\end{array}$ & 0.830 \\
\hline Power & $y=$ & $1,2 \times 1,9024$ & 0.757 \\
\hline
\end{tabular}

The calculation algorithm for blue channel using 16 data of TSS value has shown in Table 3 where from the table it is seen that for each model has the value of R2 which varies and the highest value is shown in cubic model with $\mathrm{R} 2=0.818$, while the calculation for green channel are shown in Table 5.

The result of the calculation algorithm for blue channel in Table 4 have shown a little difference with the green channel in Table 5, the higher value of $\mathrm{R} 2$ for blue channel is 0.818 while the green channel is 0.830 . Both of them came from the Cubic model of algorithm.
Table 6. Algorithm Model of Band 4 (Red Band ) from Landsat 8 OLI

\begin{tabular}{lll}
\hline $\begin{array}{l}\text { Model Algo- } \\
\text { rithm }\end{array}$ & Mathematical equation & $\mathrm{R} 2$ \\
\hline Linier & $\mathrm{y}=637,52 \mathrm{x}-7,8454$ & 0.883 \\
Exponent & $\mathrm{y}=15,124 \mathrm{e} 13,073 \mathrm{x}$ & 0.887 \\
Logaritmic & $\mathrm{y}=55,31 \ln (\mathrm{x})+$ & 0.864 \\
& 183,07 \\
Quadratic & $\mathrm{y}=1751,4 \mathrm{x} 2+322,68 \mathrm{x}$ & 0.883 \\
& $+6,1261$ \\
Cubic & $\mathrm{y}=46259 \mathrm{x} 3-10714 \mathrm{x} 2$ & 0.886 \\
& $+1421,8 \mathrm{x}-25,545$ & \\
Power & $\mathrm{y}=784,88 \mathrm{x} 1,1484$ & 0.880 \\
\hline
\end{tabular}

Table 7. Algorithm Model of Band 1 (Aerosol Band) from Landsat $8 \mathrm{OLI}$

\begin{tabular}{lll}
\hline $\begin{array}{l}\text { Model Algo- } \\
\text { rithm }\end{array}$ & Mathematical equation & $\mathrm{R} 2$ \\
\hline Linier & $\mathrm{y}=1482,4 \mathrm{x}-148,92$ & 0.752 \\
Exponent & $\mathrm{y}=0,9261 \mathrm{e} 29,652 \mathrm{x}$ & 0.711 \\
Logaritmic & $\mathrm{y}=199,99 \ln (\mathrm{x})+$ & 0.751 \\
& 451,77 & \\
Quadratic & $\mathrm{y}=1748,5 \mathrm{x} 2+1009,9 \mathrm{x}$ & 0.752 \\
& $-117,03$ & \\
Cubic & $\mathrm{y}=2 \mathrm{E}+07 \mathrm{x} 3-7 \mathrm{E}+06 \mathrm{x} 2$ & 0.801 \\
& $+919534 \mathrm{x}-41524$ & \\
Power & $\mathrm{y}=156408 \mathrm{x} 4,011$ & 0.714 \\
\hline
\end{tabular}

Table 8. Validation of TSS Data Algorithm with TSS Data in-situ

\begin{tabular}{rrrrr}
\hline X (UTM) & Y (UTM) & TSS1 & TSS2 & $\begin{array}{l}\text { TSS } \\
\text { insitu }\end{array}$ \\
\hline 668794,4607 & 9237556,96 & 52,2090 & 51,8191 & 55,3 \\
668918,299 & 9237786,95 & 54,6316 & 54,4584 & 52,4 \\
669088,065 & 9237979,01 & 54,2490 & 54,0329 & 53,7 \\
669282,1414 & 9238188,808 & 58,3292 & 58,7482 & 63,1 \\
669647,7817 & 9238575,298 & 62,3456 & 63,7915 & 66,3 \\
669925,8796 & 9238849,641 & 68,0195 & 71,6627 & 64,7 \\
\hline Note: & & & \\
TSS1 = algorithm from linier model & & \\
TSS2 = algorithm from exponent model & &
\end{tabular}

The algorithm model on the green channel has a R2 value that varies, from the lowest 0.712 in linier model to the highest 0.830 and this value is slightly higher than the value of R2 on the blue channel.

The value of $\mathrm{R} 2$ in the overall red channel is quite enough to compared with the blue channel and the green channel, as well as the aerosol channel shown in Table 7, for the aerosol the highest R2 value is owned by the Cubic algorithm model with a value of 0.801 , an average 0.7. For that the red channel (Band 4) on Landsat 8 is selected as the reference channel for the validation process of the modeled algorithm in Table 6 . 


\section{Validation of Algorithm}

The calculation for validation take a linier and exponent algorithm of red channel, where is for the calculation of TSS was compare with the in situ TSS, the result of the calculation has shown in Table 8.

The value of the data for TSS1 and TSS2 were statistically tested for TSS in situ using t-test for equality of mean and obtained Pearson correlation value on t-test for TSS1 of 0.839 to in situ TSS value, while in t-test for TSS 2 of 0.823 value of in situ TSS.

Table 9. Comparison of TSS Data from Satellite Images with Linier Algorithm

\begin{tabular}{lllll}
\hline $\begin{array}{l}\text { TSS_2013 } \\
(\mathrm{mg} / \mathrm{l})\end{array}$ & $\begin{array}{l}\text { TSS_2014 } \\
(\mathrm{mg} / \mathrm{l})\end{array}$ & $\begin{array}{l}\text { TSS_2015 } \\
(\mathrm{mg} / \mathrm{l})\end{array}$ & $\begin{array}{l}\text { TSS_2016 } \\
(\mathrm{mg} / \mathrm{l})\end{array}$ & $\begin{array}{l}\text { TSS_2017 } \\
(\mathrm{mg} / \mathrm{l})\end{array}$ \\
\hline 77,127 & 66,107 & 58,52 & 59,604 & 34,422 \\
88,602 & 64,959 & 61,644 & 107,737 & 64,449 \\
164,913 & 64,386 & 60,879 & 56,927 & 47,109 \\
160,913 & 60,178 & 56,225 & 61,772 & 50,998 \\
170,013 & 64,513 & 60,752 & 64,131 & 55,588 \\
111,489 & 60,178 & 63,939 & 71,972 & 49,978 \\
88,602 & 65,214 & 66,171 & 71,972 & 53,229 \\
100,077 & 59,413 & 57,819 & 75,415 & 50,615 \\
94,977 & 62,856 & 63,429 & 80,897 & 46,79 \\
106,389 & 59,03 & 56,353 & 83,001 & 48,511 \\
122,964 & 70,57 & 72,355 & 83,639 & 53,293 \\
94,977 & 55,524 & 59,795 & 69,422 & 44,176 \\
142,026 & 74,331 & 72,291 & 82,172 & 45,643 \\
130,615 & 69,103 & 71,08 & 69,613 & 49,595 \\
111,489 & 63,047 & 60,943 & 70,315 & 52,209 \\
134,376 & 61,581 & 59,222 & 60,688 & 54,632 \\
158,602 & 58,393 & 59,158 & 67,892 & 54,249 \\
170,013 & 64,959 & 50,679 & 73,12 & 58,329 \\
170,013 & 68,912 & 52,018 & 57,564 & 62,346 \\
106,389 & 66,617 & 54,377 & 63,812 & 68,019 \\
\hline & & & &
\end{tabular}

Both algorithms for linear and exponent have high correlation values so that these two algorithms can be used to predict TSS values for 2013 through 2016. The results for the interpolation calculation of TSS values are shown in Table 9 using Linear Algorithm.

$\operatorname{TSS}(\mathrm{mg} / \mathrm{l})=637,52 \cdot \operatorname{Rrs}(640)-7,8454$

Table 9 shows that in 2013 to 2014 there is a large decrease of TSS value, where the value of TSS occurs at all points of coordinates where the samplee has taken, so it can be said that in that period there has been a reduction of TSS value so that the aquatic environment at the coordinate point becomes more transparent due to the reduced solid dissolved in it.

In Figure 2, it can be seen that 2013 as a whole has a large TSS distribution value compared to other years' data. For TSS data for 2014 until 2017, it varies greatly in each observation coordinate point. At the first coordinate point it can be seen that TSS throughout 2013 and 2014 experienced a decline, the same events were found in 2014 to 2015 to then increase in 2016 even though not significant, a year later experienced a decline again in 2017. From this fact it can It is said that during the period of 2013 to 2017 when graphs were drawn at each observation point, a graph would be decreased or in other words at the first coordinate point the TSS distribution value tended to fall. As a result of decreasing the value of TSS content then slowly over time at that point there will be a reduction in sediment so that the shoreline will experience erosion slowly. This phenomenon is similar to research conducted in Thailand and in India where the coastline changed due to erosion.(Erener \& Yakar, 2012; Siripong, n.d.) .

The final result has shown as a thematic map of TSS value over the coast of Ujung Pangkah Gresik that have presented in Figure 3.

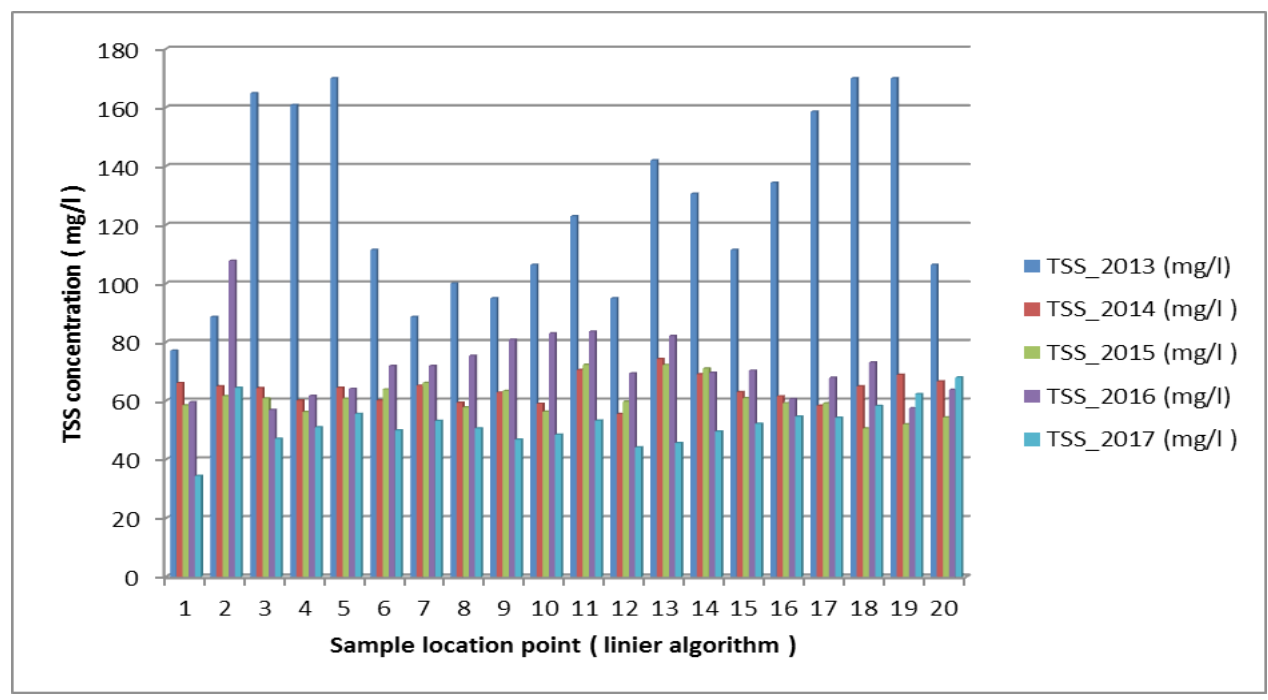

Figure 2. Comparison of TSS Value From a Variety of Year 

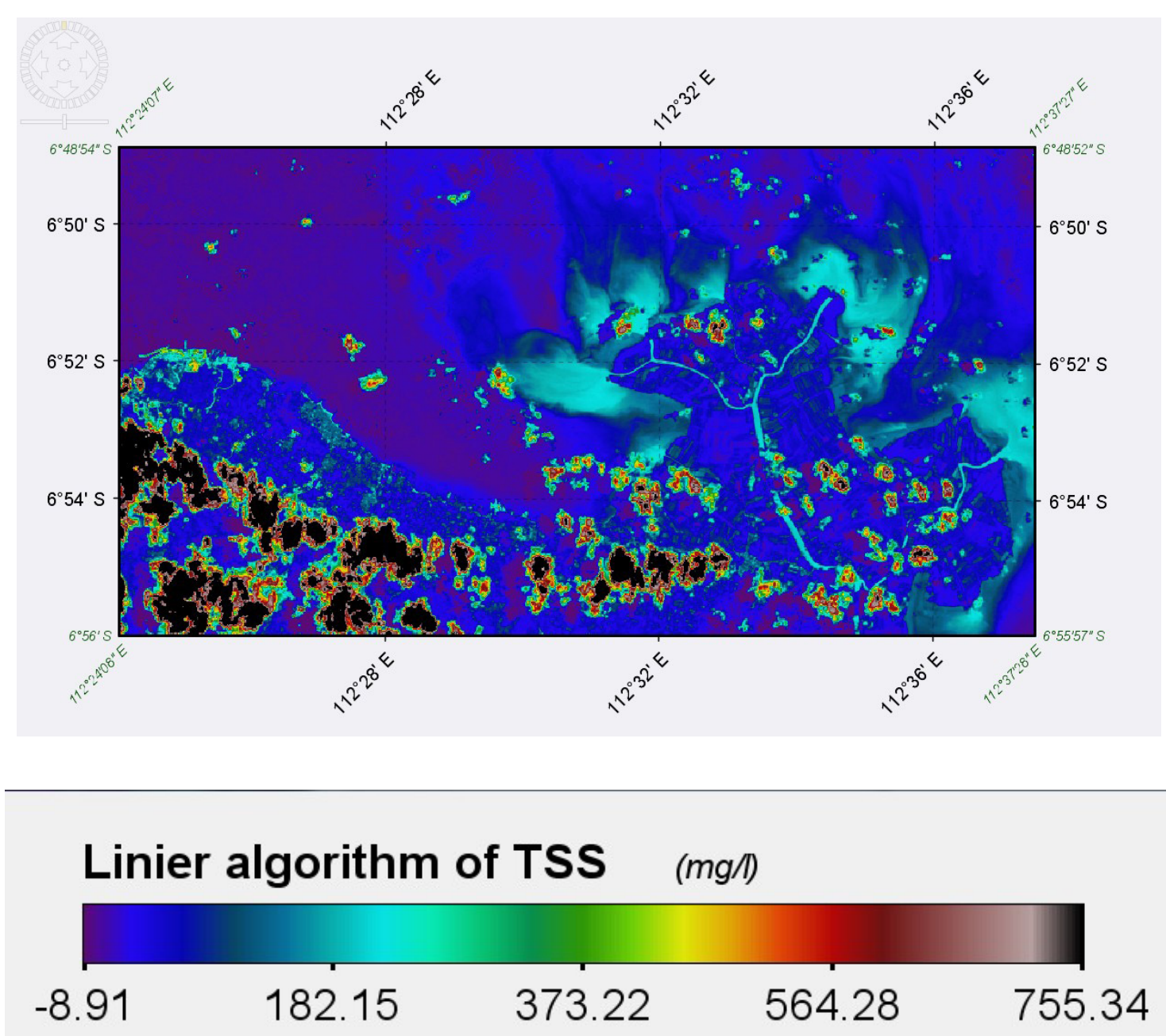

Figure 3. TSS Thematic Map at Coast Ujung Pangkah Gresik From Landsat 8 Images

\section{Conclusion}

The distribution of TSS can be monitored through remote sensing algorithms, where Landsat 8 satellite imagery plays a significant role in providing a model builder with surface reflectant value to know the distribution of TSS on the coast of Ujung Pangkah Gresik. The ability of Landsat satellite imagery to provide temporal resolution has been tested in this research, where the TSS score over 5 years statistically gives a description of the decrease of TSS value in coastal area during that time period so that the future can be done coastal assessment and management in coastal of Ujung Pangkah Gresik .

\section{Acknowledgement}

Researchers would like to thank to the Ministry of Research and Higher Education who has provided scholarship for doctoral education so that this research can be prepare well. Also thanks to Mrs Marian Rosidi who has helped translate this paper and the last to my student at Civil Engineering UPN Veteran East Java who has help as a field surveyor.

\section{References}

Baxter, T. E. (2017). Standard Operating Procedure Total Dissolved Solids by Gravimetric Determination. Retrieved from https://www.cefns.nau.edu/ teb/ambl/ sop/SOP_AMBL_105B_TotalDissolvedSolids.pdf

Cavalli, R. M. (2017). Retrieval of Sea Surface Temperature from MODIS Data in Coastal Waters. https://doi. org/10.3390/su9112032

Chen, S., Han, L., Chen, X., Li, D., Sun, L., \& Li, Y. (2015). Estimating wide range Total Suspended Solids concentrations from MODIS 250-m imageries: An improved method. ISPRS Journal of Photogrammetry and Remote Sensing, 99, 58-69. https://doi.org/10.1016/j. isprsjprs.2014.10.006

Claverie, M., Vermote, E. F., Franch, B., \& Masek, J. G. (2015). Evaluation of the Landsat-5 TM and Landsat-7 ETM+ surface reflectance products. Remote Sensing of Environment. https://doi.org/10.1016/j.rse.2015.08.030

DAAC, N. L. (2017). Landsat 8 OLI Level 1 Precision Terrain Corrected Registered At-Sensor Radiance. Retrieved from https://lpdaac.usgs.gov/citing_our_data

Dorji, P., \& Fearns, P. (2016). A quantitative comparison of total suspended sediment algorithms: A case study of the last decade for MODIS and landsat-based sensors. Remote Sensing, 8(10). https://doi.org/10.3390/ rs8100810

Dunn, R., Zigic, S., Burling, M., \& Lin, H.-H. (2015). Hydrodynamic and Sediment Modelling within a Macro 
Tidal Estuary: Port Curtis Estuary, Australia. Journal of Marine Science and Engineering, 3(3), 720-744. https:// doi.org/10.3390/jmse3030720

Erener, A., \& Yakar, M. (2012). Monitoring Coastline Change Using Remote Sensing and GIS Technologies. International Conference on Earth Science and Remote Sensing, 30, 310-315.

Guillou, N., Rivier, A., Gohin, F., \& Chapalain, G. (2015). Modeling Near-Surface Suspended Sediment Concentration in the English Channel. Journal of Marine Science and Engineering, 3(2), 193-215. https:// doi.org/10.3390/jmse3020193

Hou, X., Feng, L., Duan, H., Chen, X., Sun, D., \& Shi, K. (2017). Fifteen-year monitoring of the turbidity dynamics in large lakes and reservoirs in the middle and lower basin of the Yangtze River, China. Remote Sensing of Environment, 190, 107-121. https://doi.org/10.1016/J. RSE.2016.12.006

Hwang, D.-J., Choi, J.-K., Ryu, J.-H., \& Frouin, R. (2018). Estimating GOCI daily PAR and validation. In R. J. Frouin \& H. Murakami (Eds.), Remote Sensing of the Open and Coastal Ocean and Inland Waters (p. 4). SPIE. https://doi.org/10.1117/12.2500061

Kari, E., Kratzer, S., Beltrán-Abaunza, J. M., Harvey, E. T., \& Vaičiūte, D. (2017). Retrieval of suspended particulate matter from turbidity - model development, validation, and application to MERIS data over the Baltic Sea. International Journal of Remote Sensing, 38(7), 19832003. https://doi.org/10.1080/01431161.2016.1230289

Ozesmi, S. L., \& Bauer, M. E. (2002). Satellite remote sensing of wetlands. Wetlands Ecology and Management, 10(5), 381-402. https://doi.org/10.1023/A:1020908432489

Shuchman, R. A., Leshkevich, G., Sayers, M. J., Johengen, T. H., Brooks, C. N., \& Pozdnyakov, D. (2013). An algorithm to retrieve chlorophyll, dissolved organic carbon, and suspended minerals from Great Lakes satellite data. Journal of Great Lakes Research, 39(S1), 14-33. https:// doi.org/10.1016/j.jglr.2013.06.017
Siripong, A. (n.d.). DETECT THE COASTLINE CHANGES IN THAILAND BY REMOTE SENSING. Retrieved from http://www.isprs.org/proceedings/xxxviii/part8/ pdf/W09O24_20100226133356.pdf

Sullivan, D. G., White, J. G., \& Vepraskas, M. J. (2017). Using Land-Use Change, Soil Characteristics, and a SemiAutomated On-Line GIS Database to Inventory Carolina Bays. Wetlands, 37(1), 89-98. https://doi.org/10.1007/ s13157-016-0842-8

Tan, C. W., Thishalini, A., Goh, E. G., \& Edlic, S. (2017). Studies on turbidity in relation to suspended solid, velocity, temperature, $\mathrm{pH}$, conductivity, colour and time. ARPN Journal of Engineering and Applied Sciences, 12(19), 5626-5635.

Thiruvenkatasamy, K., \& Baby Girija, D. K. (2014). Shoreline evolution due to construction of rubble mound jetties at Munambam inlet in Ernakulam-Trichur district of the state of Kerala in the Indian peninsula. Ocean and Coastal Management. https://doi.org/10.1016/j. ocecoaman.2014.09.026

Wang, C., Chen, S., Li, D., Wang, D., Liu, W., \& Yang, J. (2017). A Landsat-based model for retrieving total suspended solids concentration of estuaries and coasts in China, 105194, 4347-4365. https://doi.org/10.5194/gmd-104347-2017

Wibisana, H., Sukojo, B. M., \& Lasminto, U. (2018). PENENTUAN MODEL MATEMATIS YANG OPTIMAL SUHU PERMUKAAN LAUT DI PANTAI UTARA GRESIK BERBASIS NILAI REFLEKTAN CITRA SATELIT AQUA MODIS. GEOMATIKA, 24(1), 31. https://doi.org/10.24895/JIG.2018.24-1.771

Zhang, F. F., Zhang, B., Li, J. S., Shen, Q., Wu, Y., \& Song, Y. (2011). Comparative analysis of automatic water identification method based on multispectral remote sensing. Procedia Environmental Sciences, 11(PART C), 1482-1487. https://doi.org/10.1016/j.proenv.2011.12.223 